\title{
EMERGING EDUCATIONAL DESIGN IN ONLINE TRAINING IN HIGHER EDUCATION
}

PROBLEMS

OF EDUCATION

IN THE $21^{\text {st }}$ CENTURY

Vol. 79, No. 3, 2021

397

\author{
María Rosa Fernández-Sánchez \\ University of Extremadura, Spain \\ E-mail: rofersan@unex.es \\ Juan Silva-Quiroz \\ University of Santiago, Chile \\ E-mail: juan.silva@usach.cl
}

\begin{abstract}
Universities are living in a time of major transitions regarding the challenge of rethinking and transforming the current pedagogical models so they can respond to the needs of the global knowmad society. In this study, the Design-Based Research (DBR) approach is used to address the improvements of two emerging pedagogical designs in e-learning in the university context: the model of the Center for Research in Education and ICT (CIIET) of the University of Santiago de Chile (Chile) and the model developed by the Education Node research group of University of Extremadura (Spain). The main focus of these models is the student, who by developing activities based on the resolution of a contextualized problem and using new strategies, accompanied by open resources for resolution, resulting in a learning outcome that can be achieved and measured through assessment. This work aims to advance in identifying of some pedagogical keys for the design of online training scenarios that promote environments of production, research, and open dissemination of best practices, to experience new creative forms and collaborative learning, which have emerged within the hyper connected society and the net-culture.
\end{abstract}

Keywords: instructional design, higher education, open educational resources, research-based design

\section{Introduction}

In the world of education, particularly in Universities, there is a pressing challenge of responding to a hyper-connected social reality. To a large extent, as Potyrala (2020) points out, new trends in educational research stem from the processes of technological development, an issue that particularly affects higher education. These are times of exponential changes and a liquid reality (Bauman, 2013), full of uncertain problems, where the relationships established through technology extend our sociability to the point of being considered by some authors as the third evolutionary force of humanity (Nowak \& Highfield, 2011). The challenge faced is of forming students who can perform adequately, as active, and participating citizens in a global knowmad society (Barak, 2017; Moravec, 2008, 2013). Studies argue that in two years, half of the professionals entering the world of work will be knowmads (Roca, 2016). These are professionals with high capacities for creativity, collaborative work, informal learning, critical thinking, among others, and are potential executors of a social change that will bring on new ways of participating and collaborating in all sectors of society (Cobo, 2011). Universities have an essential challenge in transforming teaching models that respond to unique social needs. They have to break traditional teaching models and address new pedagogies based on learning by doing, meaningful learning and experience-based learning (Tapscott, 2009). To extend their learning opportunities only beyond the university stage to lifelong learning, university students need to develop digital competence (European Commission, 2015). The current challenge of 
PROBLEMS

OF EDUCATION IN THE $21^{\text {st }}$ CENTURY Vol. 79, No. 3, 2021

398

higher education institutions should point to a more meaningful practice, integrating the use of ICTs in convergence, in a way that the traditional roles between learners and experts may be hidden (Goodfellow, 2011). Teaching practice should convey the ability to learn by creating, reconfiguring, unlearning, and re-learning, connecting classroom learning with that which occurs outside school (Cobo, 2016).

\section{Online Training Models in the University Environment}

To renew higher education implies a change of roles of all participants involved in the teaching-learning process, where students become managers of their learning, being autonomous and self-regulated (Prendes \& Roman, 2017). It is necessary to rethink the different elements and actors that give life to training: teachers, students, materials, evaluation, contents, activities, technologies, and methodologies. Those that favor the active role of the student, meaningful learning, collaboration, and autonomy, in which digital technologies to deliver added value are especially relevant (Silva \& Maturana, 2017). It is necessary to seek a model of university in digital times, to account for the digital transformation of education in which teachers are supposed to include new methodologies in the classroom that make teaching more attractive by deflecting or minimizing students' disconnection (Duart, 2019).

One aspect of consideration is the digital world in which university students are involved. The literature shows that there is no homogeneous digital generation; different profiles derive from access to technological devices, the hours of exposure to them, and the types of use (Kennedy et al., 2009). There is an emphasis on the differentiated use of technologies of young people. They have technological skills they use in leisure and social activities but are not able to transfer these skills directly to their learning and knowledge construction processes (Escofet et al., 2012).

The relationship between the new generations and the digital world can be sorted by the emphasis into three categories: the widespread use of ICT, the impact of the digital immersion particularly in learning, the personal characteristics and characteristic behavior of this generation (Bullen et al., 2011). The last two categories have particular relevance in the implementation modalities of open distance and flexible learning, such as those offered on online platforms, MOOC, M-learning, Serious Game, among other technologies that are instrumental to e-learning. Thus, the innovative use of ICTS first needs to make students the leading players of their own learning, allowing them to voice their opinion, interact and contribute knowledge to the network (Pedró, 2006).

In some universities, new pedagogical designs are emerging that attempt to respond to the training needs of the young university students of today. These models break with the traditional approach of information transfer. They are resorting to models focused on learning in which teachers guide and direct a process of knowledge construction in active and collaborative learning, seeking practical understanding of knowledge (Sawyer, 2014), thus considered disruptive models (Acaso \& Manzanera, 2015). The main focus of these models is the student, who by developing activities based on the resolution of a contextualized problem and using new strategies, resulting in a learning outcome that can be achieved and measured through assessment. Characteristically, these models use and provide open educational resources, from the conception that knowledge should be free and open for use and reuse, fostering collaboration, sharing experiences and knowledge, and the development of communities of practice from the principles of the movement of "Open Education" (Valverde, 2010). From this perspective of open teaching, the pedagogical emphasis lies in the learning network and connections of students within and through their networks (Weller, 2014). In students, this generates a greater sense of belonging toward what they learn. 
These new emerging learning experiences expand beyond the institutional realm, understanding that knowledge is distributed in an interdependent network, according to connectivist conceptions (Siemens, 2005). One of the keys to connectivism is the array of possibilities of technologies to collaborate and share within a community (Downes, 2013). In this context, it refers to the concept of expanded education, which relates to education outside educational institutions and formal processes, which shatters the borders between the more academic field and the informal context (Freire, 2012). Education is also ubiquitous, assumed as that which occurs in any place and at any time thanks to the use of new technologies (Barragán Sánchez et al., 2013; Burbules, 2014; Yahya et al., 2010). Thus, the idea of transparency, production, and dissemination of information is vital to promote the creation of collective knowledge from a perspective of free access and the momentum of innovation from higher education.

This contextual perspective raises questions such as: What characterizes online pedagogical designs that are being implemented in Higher Education institutions at an international level? Based on what theoretical models? What improvements can be incorporated into the pedagogical design of online training? To answer these questions, two pedagogical proposals from two international institutions with different contexts have been selected. The pedagogical designs of two different modalities of online training (Diploma and Master programs) have been selected and contrasted, one offered by the Universidad de Santiago de Chile through the virtual campus of the CIIET (Center for Research and Innovation in Education and ICT) and the other, by Universidad de Extremadura through its virtual campus (CVUEx). The design proposed by Universidad de Extremadura is part of the Educational Node research group and the University Master's Degree in Digital Education. The model of the CIIET relates to the research team of this center developed through its virtual campus in the qualifications of diploma and continuing education programs. This research of two proposals will allow us to identify some pedagogical keys for the design of online training scenarios in the context of higher education. These settings should promote production environments, research, and dissemination of best practices, to experience the creative new ways and collaborative learning that have emerged within the hyper-connected society and culture-network, from an expanded and open education perspective.

\section{Research Methodology}

\section{General Background}

Design-Based Research (DBR) model related to Brown (1992) is the base of our methodological approach. Brown is considered the pioneering author of this approach with her article published in the Journal of the Learning Sciences on the introduction of innovations from the field of educational technology from a theoretical-practical perspective of experiencing a theoretical design in instructional practice. The Design-Based Research (DBR) model in the field of educational technology is to develop design of artifacts, technological tools, and pedagogical designs from existing theories or to develop new theoretical frameworks that support and lead to a deeper understanding of learning processes (Barab et al., 2007; Barab \& Squire, 2004; Fishman et al., 2004). The DBR is a type of exploratory research that highlights the value of novelty and supports non-conventional and creative approaches (Kelly, 2006).

Richey et al. (2003) promote the use of this type of research to contrast theoretical instructional models and to undertake innovation processes that improve practice. This study addresses both interpretations. The research process is through continuous cycles of design, validation, analysis, and redesign, leading the different iterations toward improving the body of theory and perfecting the intervention. From this point of view, the DBR in this research 
PROBLEMS

OF EDUCATION

IN THE $21^{\text {st }}$ CENTURY Vol. 79 , No. 3, 202

400

aims to identify variables to characterize the situation and improve the implemented design by generating guidelines for the implementation of educational designs for online training in the two selected contexts.

This DBR contributes to the generation of knowledge to improve the quality of the pedagogical model for online training in both contexts and to understand how innovations can work in practice.

\section{Case Selection}

Two case studies were selected taking into account the two e-learning pedagogical designs as the unit of analysis. The selection considered the scientific trajectory in research and innovation projects related to pedagogical models in digital education at the University. Both cases seek the continuous improvement of the pedagogical designs they propose oriented towards the quality of teaching in the implementation of the design and the development of innovative educational practices that produce deep learning.

The first case corresponds to the pedagogical model of the Master's Degree in Digital Education proposed by the Nodo Educativo research group (SEJ095) of the University of Extremadura (Spain). This group has been working since 2001 on the integration of technologies in educational contexts and pedagogical models in e-learning and blended learning environments at national and international level. As of 2014, this Group has been working on the continuous improvement of the pedagogical model of the Master in Digital Education, an official online degree of the group's reference University.

The CIIET (Center for Research and Innovation in Education and ICT) of Universidad de Santiago de Chile (Chile) has been working on the implementation of training solutions with technologies at national and international level for over 20 years. They are specialists in instructional design with digital technologies and work in the design of online training for the University and for many public and private entities.

\section{Procedures, Task and Data Analysis}

The DBR model has three phases, within a flexible and iterative structure: analysisexploration, design-construction, and evaluation-reflection. It has a dual focus on theory and practice and oriented toward teaching practice: planning the implementation and dissemination, context-sensitive, and in interaction with the educational practices (Hathaway \& Norton, 2018; Huang et al., 2019; Plomp \& Nieveen, 2010). According to Bell (2004), studies from the DBR approach focus on the research, exploration, and design of educational innovations at the didactic and organizational level, improving the designs.

After the first exploratory phase, during which the theoretical review and the definition of contexts, pedagogical models and planning of data collection with the design and development of research instruments are carried out, the implementation phase is conducted. The latter includes microcycles in which design problem conjectures are formulated based on the instructive context of each case. Data sources are then accessed, compiling all the available information. The final phase is of reflection, in which a retrospective analysis is carried out and the design is reconstructed with the methodological strategies for improvement. The phases followed in the study and the tasks performed are presented below. 
Table 1

Phases and Tasks

\begin{tabular}{|c|c|c|}
\hline \multirow{5}{*}{$\begin{array}{l}\text { Phase 1. Analysis and exploration. } \\
\text { Preparing the design. }\end{array}$} & 01 & Definition of goals \\
\hline & 02 & Description of base contexts and situation \\
\hline & 03 & Definition of theoretical intentions \\
\hline & \multirow{2}{*}{04} & Design of the intervention \\
\hline & & Definition of data sources \\
\hline \multirow{3}{*}{$\begin{array}{l}\text { Phase 2. Design and construction. } \\
\text { Implementation. }\end{array}$} & \multirow{3}{*}{05} & Microcycle of design (problematics) \\
\hline & & Microcycle of analysis \\
\hline & & $\begin{array}{l}\text { Review of learning documentation and products (recording of } \\
\text { document analysis) }\end{array}$ \\
\hline \multirow{4}{*}{$\begin{array}{l}\text { Phase 3. Analysis and reflection. } \\
\text { Retrospective analysis. }\end{array}$} & 06 & Data analysis (qualitative content analysis) \\
\hline & 07 & Suggested indications \\
\hline & 08 & Reconstruction of designs: pedagogical models \\
\hline & 09 & Elaboration of conclusion and recommendations (Redesign) \\
\hline
\end{tabular}

The process of analyzing the data obtained in the process of collecting information was carried out through qualitative content analysis by means of a process of coding and categorization of data through three stages (Hernández-Sampieri et al., 2010): (1) open coding: emerging categories were identified from reading the data, shaping and reviewing these categories from new approaches to the data, comparing them, and consulting them, and the consultation of specialized literature; (2) selective coding: a process that enables reducing the initial set of categories, from the intensive analysis of the relationships between the central category and the rest; (3) theoretical coding: allowing for deliberation on the properties, dimensions, elements contained in the central category, reaching an increasingly higher level of explanation for the research problem.

From data analysis, the redesign of the pedagogical models is proposed with the improvement of methodological strategies in each of the selected proposals.

\section{Research Results}

\section{Analysis and Exploration of the Online Learning Models}

At first, the selected designs are explored and analyzed in the context of the digital campuses in which they are implemented: pedagogical model of CIIET and Master in Digital Education -MDE- (Educational Node RG) teaching model.

The pedagogical model of CIIET is based on the generic ADDIE (Analysis, Design, Development, Implementation and Evaluation) model of instructional design supplemented with elements of the ASSURE model and the Kemp model (Muñoz, 2011). Its overall instructional design is based on an interactive process where the results of the formative evaluation of each phase can go back to the previous stages in the process of continuous quality and improvement. The underlying theoretical approach is based on the model of Community of Inquiry (CoI) by Garrison and Anderson (2005) with its three components: social presence, cognitive presence, 
PROBLEMS

OF EDUCATION

IN THE $21^{\text {st }}$ CENTURY

Vol. 79 , No. 3, 202

402

and teaching presence. Active and collaborative methodologies are at the core of this pedagogical model based on e-activities (Salmon, 2004) to achieve the learning objectives. They start with the first definition of the characteristics of the participants, previous knowledge of the course, level of use of digital technologies, and elements of andragogy. Other aspects of the course are articulated from the e-activities, such as communication, content, tools of the platform, learning resources, evaluation, etc. However, contents do not disappear, but they are at the service of the activity to aid in resolving the proposed tasks. This condition forces the teacher to think of the activities as the main element and the content as a quality resource for the tasks set out. Tutoring uses the model of e-moderating (Salmon, 2000), which defines the presence of teachers.

\section{Figure 1}

The Pedagogical Model of CIIET by Silva (2017)

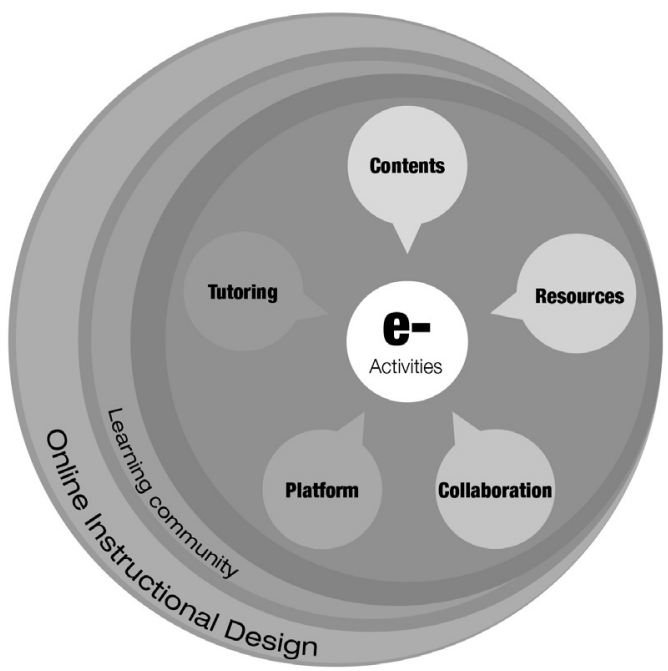

The MDE pedagogical model is based on three approaches derived of constructivist learning theories. One is the instructional principles of Merril (2002), another the TPACK model (Technological Pedagogical Content Knowledge) (Koehler \& Mishra, 2006), and finally, the Community of Inquiry (CoI) model by Garrison and Anderson (2005). The five principles of Merrill (2002, is an effective teaching model established for problem-oriented, involving the student in four phases through the proposed activities. It applies (A) activation of previous experiences; (b) demonstration of competencies and skills; (c) application of competencies and skills, and (d) integration of these skills in real-world activities. From the TPACK model (Koehler \& Mishra, 2006, 2008) articulated in the MED pedagogical, the relationships between curricular content, technology and pedagogy are articulated, allowing for reflection within multiple domains of knowledge. There are three types of knowledge that are involved in this mode: declarative (knowing what, which includes definitions, terms, facts and descriptions), procedural (knowing how, i.e., sequences of steps for completing a task or subtask), schematic (knowing why; drawn from the two previous knowledge types, creates principles and mental models), and strategic (knowing when and where to use a particular piece of knowledge and strategies such as planning and troubleshooting along with control of the progress toward a goal). The CoI model (Garrison et al., 2001) argued that knowledge in virtual teaching-learning environments is constructed through developing a community of inquiry characterized by three presences: teaching, social and cognitive. In lieu of face-to-face interaction, participants in virtual learning environments must strive to recreate social processes of knowledge construction that take place in the negotiation of meaning within the classroom. 
On the other hand, this model exercises student's motivation for achieving deep programming through the model of Attention, Relevance, Confidence and Satisfaction (ARCS) by Keller and Suzuki (2004) and Keller (2010). The ARCS model is used to design open educational resources that foster motivation toward learning from the four categories mentioned above. The starting point is at the "Attention" category, which holds motivational variables related to stimulus and keeping up the curiosity and interest of the learner. The next step is to ensure that the student believes that learning is relevant at a personal level, i.e., related to meaningful personal goals. Subsequently, it is necessary to generate adequate expectations of success, so the users of the open educational resource are not afraid or do not have misconceptions about their abilities to achieve the learning. It is also essential, so they do not overestimate their skills concerning the demands of the knowledge. Finally, to keep up their desire to learn, they must experience personal satisfaction due to the processes carried out or the results obtained through extrinsic or intrinsic reinforcements. To conclude, some guidelines of the Universal Design for Learning (UDL) by Rose and Meyer (2002) are used to provide multiple forms of involvement, representation, action, and expression.

\section{Figure 2}

\section{Pedagogical Model of MDE by Valverde (2019)}

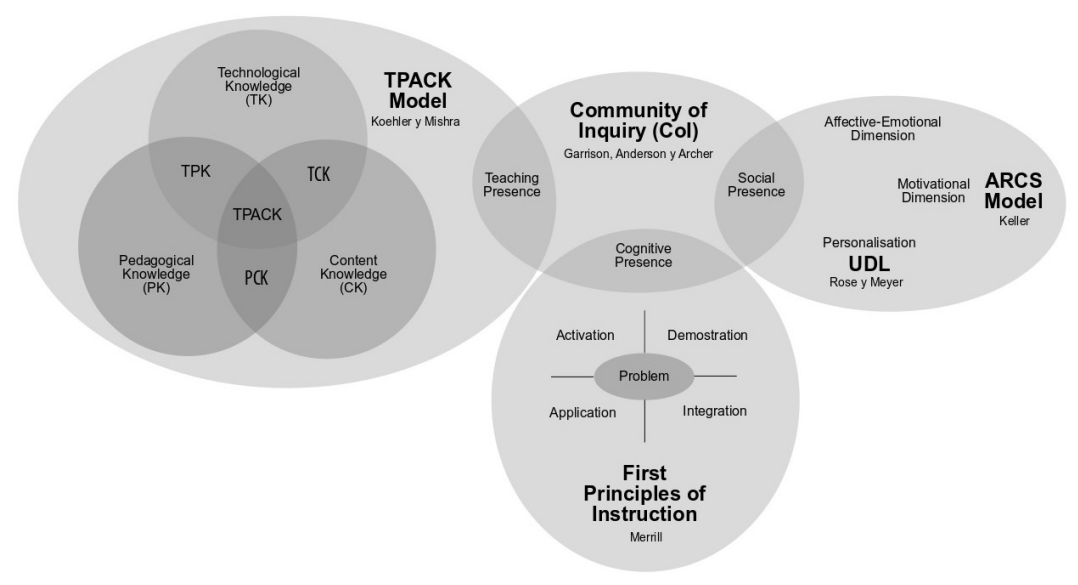

Contrast of Pedagogical Models

The design of online training developed at CIIET focuses its vision for learning on the student and the e-activities (Salmon, 2004) under the principles of active methodologies, seeking to form collaborative learning communities (Downes, 2012; Garrison \& Anderson, 2005). The second model focuses on the pedagogical design of the Master in Digital Education of the UEx, developed based on Merrill's Instructional Design Principles (2002), the model of TPACK by Koehler and Mishra (2008), the Community of Inquiry (CoI) by Garrison, Anderson and Archer (2010), the model Attention, Relevance, Confidence and Satisfaction (ARCS) by Keller and Suzuki (2004) and Keller (2010) and Universal Design for Learning (UDL) by Rose and Meyer (2002). In both designs, the learning activities are the framework that links the other elements of the environment. Both models respond to current trends in methodologies for active learning, from the approach of new ecologies of learning in virtual environments, where technology is used to enrich the work environment, to enhance communication and interaction, and to manage knowledge. As pillars of the virtual environment, active methodologies, activities (using problem-based learning), and learning assessment, along with resources, collaboration, and the presence of teachers are articulated. Learning strategies that are used to motivate

$\mid$\begin{tabular}{l} 
PROBLEMS \\
OF EDUCATION \\
IN THE 21 $21^{\text {st }}$ CENTURY \\
Vol. 79, No. 3, 2021 \\
\hline 403
\end{tabular} 
PROBLEMS

OF EDUCATION

IN THE $21^{\text {st }}$ CENTURY Vol. 79, No. 3, 2021

404

students respond to emerging models related to activities based on real cases and problems, digital narratives, gamification systems, among others. In the case of the Master's, activities are proposed as webquest integrated as tasks to be achieved in the development of a research project or case study. In the case of the CIIET, the approach responds to case of study or is based on practical problems that the student must resolve as a challenge. In both cases, the open learning resources and communicative spaces are transversal axes in achieving learning goals.

\section{Design-construction: Implementation of the Pedagogical Models in Virtual Environments.}

The study of the implementation of the pedagogical models in virtual learning environments is performed in the LMS platforms of both models, which in both cases is Moodle. The results of both applications over four years respond to disruptive models that lead to satisfaction and student motivation, which has an impact on the development of deep learning.

a. Implementation of the pedagogical model of CIIET in virtual environments.

This model is technically structured through a virtual classroom in Moodle, organized through icons that show a visual environment that is accessible through multiple devices (PC, tablet, or smart phone). This visual representation (ad hoc interface with the theme of each training) is related and hyperlinked to each other, allowing the student to explore the pedagogical design without a predefined route. The permanent elements of each formation represented in icons are guidance, social and doubts, the course program, a video that introduces the course hosted by each teacher, and the synthetic view that shows the learning path. The rest of the training modules are accessed through these elements. Each module contains a group icon arranged in the form of a network that includes e-activities as the center of the graphic representation, from where the student accesses the tasks, objectives, documentation, evaluation and resources of each topic worked on. Each e-activity consists of the name, description, objectives, competencies or results of the learning process, time, and appropriation, evaluation and supporting activities. They are developed from the model by Salmon (2004), initially proposing activities for the student to adjust to the environment, for familiarizing and to collect enough initial information to make progress in learning, and activities that enable the construction of a positive work environment, stressing social presence to conform to the learning community. Subsequently, activities are proposed that relate to the progress and monitoring of student learning from the work of the teaching presence. The e-events consider a variety of actions or productions that involve using different web resources, such as collaborative construction of documents, conceptual maps, preparing presentations, generating infographics, video design, etc. All of this is proposed to promote practical work, in teams, related to specific situations aimed at problem solving or the development of higher-order skills in students, responding to the cognitive dimension of the CoI model.

The implementation of the CIIET design has been evaluated by assessing student satisfaction with the knowledge attained through this model in online training (Silva, 2017). Students showed general satisfaction (over 90\%) with the learning developed by the model of the implemented and experienced e-activities. As an improvement, students suggest (10\%) to insist on the coherence between activities and content through open educational resources that act as a support in the e-activities.

b. Implementation of the pedagogical model of MDE in virtual environments.

The MDE model is technically structured locating activities in the first phase, followed by communication tools, content and multimedia resources. The subjects are developed through 
a webquest type activity that requires the resolution of a problem situation, which involves the implementation of a variety of coordinated skills, knowledge, and attitudes. This requires the use of new tools (software), the implementation of high-level cognitive skills (synthesis, argument, integration, creation) and the development of self-regulatory behaviors. It includes a rubric to inform students of the assessment criteria in the process. The learning activity starts with a problem situation of an educational phenomenon on which the student has a direct or indirect experience, an initial point of view, and knowledge (personal theories) to categorize, analyze and describe its causes-effects. All activities involve developing a product to be distributed in open mode afterward, which implies the application of inquiry, synthesis, and integration of information, fieldwork, among others. From a starting point that is close to students' experience, a "cognitive dissonance" is triggered to generate curiosity and encourage the attitude of inquiry. This dissonance occurs assuming roles indicated by the webquest (an educational consultant, journalist, a member of a tribunal, etc.) and in posing the task in which divergence, divergence, reflection, and reformulation of pre-conceptions are sought. The pedagogical design of the Master's program prevents the simultaneity of learning activities. The purpose of this is so that the student only has to deal with one task in a given period, thus controlling the compulsory cognitive load to carry out the webquest. The evaluation offers feedback for the student to know their progress and enables establishing consensus in cases of discrepancy in the evaluative process. In this Master's, the virtual environment for teaching-learning is not considered merely a tool for distance education. It is, in itself, a learning object, because it is imperative for students to practically and personally experience everything that is assumed in learning in training in digital education, through telematics networks. The figure of "social-emotional attention" in the development of the Master's, which aims to identify the emotional states of the students in the process, guiding them, promoting effective communication and integration into the learning community, and ensuring positive emotional development of the virtual student.

In the case of the MDE pedagogical model, the study assessed whether the approach had an impact on the achievement of deep programming (Valverde et al., 2018). For this purpose, we used the SOLO Taxonomy by Biggs and Collis (1982). Their results showed that students perceived, on the one hand, an initial uncertainty in the development of online training courses that do not follow the traditionally established order. On the other hand, they faced the activity with greater confidence in their own abilities, with the expectation of achieving results of deep learning at the end. They concluded that the approach of this model through the development of complex activities using webquest fit the development of deep learning.

\section{Evaluation, Proposal and Pedagogical Guidelines}

The study and contrast of these two pedagogical models, through an iterative process and application software, allows three possible fundamental developments that help improve the dimensions less developed in both approaches.

- In the first place, new approaches should integrate the current design in the two models. In both cases the model of Digital Game-Based Learning (DGBL) may be the right approach to obtain student commitment and increased motivation. Both designs need to delve deeper into developing an affective-emotional dimension based on robust theoretical approaches that demonstrate the effectiveness of the pedagogical practices in developing student commitment and motivation in online training. This approach takes from the work of Prensky (2001) as a pedagogical model to achieve student engagement with the conjunction of serious learning and entertainment in a new environment in which they seek excitement to learn as the motivational element. Many later studies have demonstrated the potential of the Digital Game-Based Learning (DGBL) in educational environments, showing a positive correlation between the 
PROBLEMS

OF EDUCATION

IN THE $21^{\text {st }}$ CENTURY Vol. 79, No. 3, 2021

406

activities of play and learning (Backlund \& Hendrix, 2013; Connolly et al., 2011; Sung et al., 2013).

- In the case of the CIIET model, a motivational model of reference should be added for the development of open educational resources. The model of Attention, Relevance, Confidence, and Satisfaction (ARCS) by Keller (2010) is suggested, implemented on the model of the MED with positive results. This model allows for the development of open educational resources from motivational variables that generate relevant expectations of success. This maintains students' desire to learn throughout the process and reduces the fear or misperception of their own ability to meet the learning achievements. Maintaining students' desire to learn with confidence, in turn, improves the coherence between activities and content, suggested by students, through the development and selection of these open educational resources.

- In the case of the model of the MDE, it is recommended to study and improve the graphic designs of the online environments to fit the activities proposed for each model and theoretical approaches adopted. If the intention is to immerse the student in the environment to improve motivation and commitment to learning, it is necessary to work in graphic designs that accompany the pedagogical designs proposed and rethink from a Universal Design for Learning (Rose \& Meyer, 2002).

After analyzing and elaborating the improvement considerations for the models analyzed, three preliminary pedagogical guidelines were identified to advance the study of pedagogical models for a more groundbreaking approach in online training from an open and flexible perspective:

1. Multiple theoretical approaches for a complex pedagogical design. The option to think of a model of online training must respond to multiple theoretical approaches that constitute a solid pedagogical model. Each model must respond to the needs of the offered learning environments, the applied strategies, the addressed topics, etc.

2. Proactive pedagogical design for online training to promote the use of active and interactive teaching. From a proactive approach, pedagogical designs focus on the activity of the student. Through activity design, student commitment with the key elements of the training content and with available open educational resources must be sought to attain deep learning. Communication design should focus on active learning experiences and dynamic interactivity.

3. The approach of pedagogical models must rethink the roles of teachers and students in online training. It is necessary to rethink, reshape, and redefine what it means to teach and learn in the online world from perspectives of open education.

\section{Discussion}

With the generalization of digital education, especially in higher education, it is necessary to know the pedagogical models and effectively implemented underlying strategies. Systematically studying the process of design, development, and implementation of pedagogical models in online training may guide the understanding on how to apply theoretical approaches to the process of development. The pedagogical designs analyzed respond to emerging learning proposals that allow for models of distributed learning (Acaso \& Manzanera, 2015). These designs include the participants as co-builders of shared learning (Reig, 2010), and promote the generation of new forms of cooperation and collaboration, encouraged, and implemented 
from epistemological positions that are experimental and applied (Pisticelli, 2009). The study focused on the DBR model enables improving the presented online pedagogical designs by incorporating new theories that will allow implementing a more disruptive design. It also has allowed us to begin to raise a few pedagogical guidelines in the design of online training from a perspective of open education that will lead us to the practice of dialog creation, deconstruction and rethinking of student-teacher roles from a critical approach that should always characterize these educational prospects (Farrow, 2015). Research on their impact on student learning will provide evidence that can verify the fundamental keys of these emerging online learning environments and understand and enrich the designs of these environments under the perspective of emerging pedagogies that adapt better to the demands of society in the 21 st century.

In recent years, research shows outstanding interest in the design and development of pedagogical models in online training that respond to the needs of teachers and students in the new teaching-learning environments. There is a demand for the creation of a theoretical corpus or pedagogy of e-learning that can provide a solid foundation on which to support the design of training environments effectively, as well as the need for explanatory theories about this modality based on empirical evidence (Graham et al., 2014). Although most studies on e-learning usually identify their underlying theoretical framework, how this theory translates into actual design principles is often not clearly defined. Research on these online learning environments should be more explicit about their design, as well as introduce more rigor into the pedagogical justification of teaching practices that take place in online learning environments. E-learning has been shown to be a potentially effective learning modality if the pedagogical design is carefully carried out prior to implementation (Ustun \& Tracey, 2020). The work of the faculty and the coordination that is established in the planning of the design is crucial in this matter. In fact, as early as 2010 the research by McAnally-Salas et al., concluded that interpersonal relationships among teachers can play a fundamental role in the approach to the pedagogical design of e-learning. Recent research concludes with the need to increase research in this area since educational institutions have problems conceptualizing and implementing effective online training environments (Drysdale et al., 2013; Dziuban et al., 2011). Salinas, De Benito and Gisbert (2018) point to the need to influence from research in:

1. Identifying key elements of pedagogical design and the influence on learning and desired effects.

2. Developing studies focused on digital learning, with more detailed practical experience reports that allow the understanding of nuances of "blended learning" beyond blended delivery, focusing research on the interaction between learning processes.

3. Structuring an e-learning pedagogy: hypermediality, synchrony and asynchrony, personalized scaffolding and collective scaffolding, accessibility of materials and interaction.

4. Studying the integration of constructivist and collaborative models in e-learning environments and fostering the formation of creative and curious students with these formative models.

\section{Conclusions and Implications}

After having applied the DBR to the CIIET and MDE cases, it is concluded that both proposals are valid, innovative, and up to date for online training, although it is necessary to encourage two key components of the pedagogical designs: communication and student motivation. From this point of view several challenges are identified that should be considered in these and in any pedagogical design in online training in relation to these two components: (a) student self-regulation skills and engagement with learning, keeping in mind strategies to encourage both issues in the pedagogical design; (b) digital literacy and competence of students and faculty: teacher training, resistance to technologies or lack of training in the use of digital 
PROBLEMS

OF EDUCATION IN THE $21^{\text {st }}$ CENTURY Vol. 79, No. 3, 2021

408

technologies by students; (c) strategies to avoid isolation and feelings of loneliness or problems with synchronous communication, which can cause students to abandon training; (d) access to technologies, especially by students: lack of technological devices and infrastructure, obsolete technologies, poor access to the Internet; and finally (e) technological complexity: use of interfaces, distraction derived from excessive technological complexity.

With the arrival of the COVID-19 pandemic, the adoption of e-learning models has grown exponentially in universities. From the institutional and organizational point of view, they highlight the importance of the support of university institutions for the implementation of pedagogical designs that meet the training needs of the contexts in which they are developed and that address the new training challenges that are coming in the post-pandemic society. To this end, there is a need to formulate university educational policies aimed at developing evidencebased e-learning pedagogical models supported by didactic guidelines for their implementation.

\section{References}

Acaso, M., \& Manzanera, P. (2015). Esto no es una clase. Investigando la educación disruptiva en los contextos educativos formales [This is not a classroom. Investigating disruptive education in formal educational contexts]. Ariel, Fundación Telefónica.

Backlund, P., \& Hendrix, M. (2013). Educational Games - Are They Worth the Effort? A literature survey of the effectiveness of serious games [Paper presentation]. 5th International Conference on Games and Virtual Worlds for Serious Applications (VS-GAMES), Poole, UK. http://doi.org/10.1109/VS-GAMES.2013.6624226

Barak, M. (2017). Science teacher education in the twenty-first century: A pedagogical framework for technology-integrated social constructivism. Research in Science Education, 47(2), 283-303. http://doi.org/10.1007/s11165-015-9501-y

Barab, S. A., \& Squire, K. (2004). Design-based research: Putting a stake in the ground. Journal of the Learning Sciences, 13(1), 1-14.

Barab, S. A., Dodge, T., Thomas, M. K., Jackson, C., \& Tuzun, H. (2007). Our designs and the social agendas they carry. Journal of the Learning Sciences, 16(2), 263-305.

Barragán Sánchez, R., Mimbrero Mallado, C., \& Pacheco González-Piñal, R. (2013). Cambios pedagógicos y sociales en el uso de las TIC U-learning y U-portafolio [Pedagogical and social changes in the use of ICTs U-learning and U-portfolio]. Revista Electrónica de Investigación y Docencia (REID), 10, 7-20.

Bauman, Z. (2013). Sobre la educación en un mundo líquido [On education in a liquid world]. Paidós.

Burbules, N. (2014). Los significados de "aprendizaje ubicuo" [The meanings of "ubiquitous learning"]. Education Policy Analysis Archives/Archivos Analiticos de Politicas Educativas, 22, 1-10.

Bell, P. (2004). On the theoretical breadth of design-based research in education. Educational Psychologist, 39(4), 23-253.

Biggs, J. B., \& Collis, K. F. (1982). Evaluating the quality of learning: The SOLO taxonomy (structure of the observed learning outcome). Academic Press.

Brown, A. L. (1992). Design experiments: Theoretical and methodological challenges in creating complex interventions in classroom settings. The Journal of the Learning Sciences, 2(2), 141-178.

Bullen, M., Morgan, T. \& Qayyum, A. (2011). Digital learners in higher education: Generation is not the issue. Canadian Journal of Learning and Technology, 37(1), 1-24. http://www.cjlt.ca/index. $\mathrm{php} / \mathrm{cjlt} /$ article/viewFile/550/298

Cobo, C. (2011). Uso invisible de las tecnologías y competencias para la globalidad [The invisible use of technologies and competencies for globality]. In C. Cobo \& J.W. Moravec (2011). Aprendizaje Invisible. Hacia una nueva ecología de la educación [Invisible Learning. Toward a new ecology of education]. Publicacions i Edicions de la Universitat de Barcelona.

Cobo, C. (2016) La Innovación Pendiente. Reflexiones (y Provocaciones) sobre educación, tecnología y conocimiento [Pending Innovation. Reflections (and Triggers) about education, technology, and knowledge]. Colección Fundación Ceibal/Debate: Montevideo. http://innovacionpendiente. com/descargas/la-innovacion-pendiente 
Connolly, T. M., Stansfield, M., \& Hainey, T. (2011). An alternate reality game for language learning: ARGuing for multilingual motivation. Computers \& Education, 57, 1389-1415. http://doi.org/10.1016/j.compedu.2011.01.009

Dziuban, C., Graham, C.R., Moskal, P.D., Borberg, A., \& Sicilia, N. (2018). Blended learning: The new normal and emerging technologies. International Journal of Educational Technology in Higher Education, 15(3). https://doi.org/10.1186/s41239-017-0087-5

Downes, S. (2012). Connectivism and Connective Knowledge. Essays on meaning and learning networks. http://www.downes.ca/files/Connective_Knowledge-19May2012.pdf

Downes, S. (2013). The Role of Open Educational Resources in Personal Learning. In McGreal, R., Kinuthia, W., \& Marshall, S. (Ed.), Open educational resources: innovation, research and practice (pp. 203-226). Commonwealth of Learning and Athabasca University. https://goo.gl/ $\operatorname{cdv} 8 \mathrm{Lg}$

Drysdale, J. S., Graham, C. R., Spring, K. J., \& Halverson, L. R. (2013). An analysis of research trends in dissertations and theses studying blended learning. The Internet and Higher Education, 17, 90-100. https://doi.org/10.1016/j.iheduc.2012.11.003

Duart, J. (2019). Prologue. In: Castañeda, L., \& Selwyn, N. (Ed.), Reiniciando la Universidad: Buscando un modelo de universidad en los tiempos digitales [Restarting University: Seeking a university model in digital times]. Editorial UOC.

European Commission (2015). 2015 Joint Report of the Council and the Commission on the implementation of the strategic framework for European cooperation in education and training (ET 2020) New priorities for European cooperation in education and training http://eur-lex.europa.eu/legalcontent/EN/TXT/?uri=uriserv:OJ.C_.2015.417.01.0025.01.ENG\&toc=OJ:C:2015:417:TOC

Farrow, R. (2015). Open education and critical pedagogy. Learning, Media and Technology, 42(2), 130146. https://doi.org/10.1080/17439884.2016.1113991

Fishman, B., Marx, R. W., Blumenfeld, P., Krajcik, J., \& Soloway, E. (2004). Creating a framework for research on systemic technology innovations. Journal of the Learning Sciences, 13(1), 43-76.

Freire, J. (2012). Educación expandida y nuevas instituciones: ¿Es posible la transformación? [Expanded education and new institutions: Is transformation possible? In R. Díaz; J. Freire (Eds.), Educación expandida (pp. 67-84). Zemos98 Editions.

García. I., Gros, B., \& Escofet, A. (2012). La influencia del género en la cultura digital del estudiantado Universitario [The influence of gender in the digital culture of the university studend body]. Athenea Digital: Revista de pensamiento e investigación social 12(3), 95114. http://atheneadigital.net/article/viewFile/Garcia/pdf

Garrison, D. R., \& Anderson, T., (2005). El e-learning en el siglo XXI. Investigación y práctica [E-learning in the $21^{\text {st }}$ Century. Research and practice]. Octaedro.

Garrison, D. R., Anderson, T., \& Archer, W. (2001). Critical thinking, cognitive presence and computer conferencing in distance education. American Journal of Distance Education, 15(1), 7-23.

Garrison, D. R., Anderson, T., \& Archer, W. (2010). The first decade of the community of inquiry framework: A retrospective. The Internet and Higher Education, 13(1-2), 5-9. http://doi.org/10.1016/j.iheduc.2009.10.003

Goodfellow, R. (2011). Literacy, literacies, and the digital in higher education. Teaching in Higher Education, 16(1), 131-144. https://doi.org/10.1080/13562517.2011.544125

Graham, C., Henrie, C., \& Gibbons, A. (2014) Developing models and theory for «blended learning» research. In Picciano, A.G., Dziuban, C., Graham, C.R. (Eds.), Blended learning: Research Perspectives, vol. 2 (pp. 13-33). Routledge.

Hwang, G.-J., Sung, H.-Y., Hung, C.-M., Yang, L.-H., \& Huang, I. (2013). A knowledge engineering approach to developing educational computer games for improving students' differentiating knowledge. British Journal of Educational Technology, 44(2), 183-196. https://doi.org/10.1111/j.1467-8535.2012.01285.x

Hathaway, D., \& Norton, P. (2018). Understanding problems of practice. A case study in design research. Springer International Publishing.

Hernández-Sampieri, R., Fernández, C., \& Baptista, P. (2010). Metodología de la Investigación [Research Methodology]. McGraw Hill.

Huang, R., Spector, J. M., \& Yang, J. (2019). Design-based research. En R. Huang, J. M. Spector, y J. Yang (Eds.), Educational Technology (pp. 179-188). Springer.

Keller, J. (2010). Motivational design for learning and performance: the ARCS model approach. Springer.

$\mid \begin{aligned} & \text { PROBLEMS } \\ & \text { OF EDUCATION } \\ & \text { IN THE } 21^{\text {st }} \text { CENTURY } \\ & \text { Vol. 79, No. 3, } 2021\end{aligned}$

409 
María Rosa FERNÁNDEZ-SÁNCHEZ, Juan SILVA-QUIROZ. Emerging educational design in online training in higher education

PROBLEMS

OF EDUCATION

IN THE $21^{\text {st }}$ CENTURY Vol. 79, No. 3, 2021

410

Keller, J., \& Suzuki, K. (2004). Learner motivation and E-learning design: A multinationally validated process. Journal of Educational Media, 29(3), 229239. http://doi.org/10.1080/1358165042000283084

Kelly, A. E. (2006). Quality criteria for design research: Evidence and commitments. In Van den Akker, J., Gravemeijer, K., McKenney, S., \& Nieveen, N. (Eds.) (2006), Educational design research (pp 107-18). Routledge.

Kennedy, G., Judd, T. S., Churchward, A., Gray, K., \& Krause, K.-L. (2008). First year students' experiences with technology: Are they really digital natives? Australasian Journal of Educational Technology, 24(1), 108-122. http://doi.org/10.14742/ajet.v24i1.1233

Koehler, M. J., \& Mishra, P. (2008). Handbook of technological pedagogical content knowledge (TPCK) for educators. Routledge for the American Association of Colleges for Teacher Education.

McAnally-Salas, L., Lavigne, G., \& de Vega, C.A. (2010). Online course instructional design. From the professor'pedagogic knowledge and technological skills. Problems of Education in the 21st Century, 19, 84-93. http://www.scientiasocialis.lt/pec/node/360

Merrill, M. D. (2002). First principles of instruction. Educational Technology Research and Development, 50(3), 43-59. http://doi.org/10.1007/BF02505024

Moravec, J. W. (2008). Knowmads in society 3.0. Education Futures. http://www.educationfutures. com/2008/11/20/knowmads-in-society-30/

Moravec, J. W. (2013). Knowmad society: The "new" work and education. On the Horizon, 21(2), 79-83, https://doi.org/10.1108/10748121311322978

Muñoz, P (2011). Modelos de diseño instruccional utilizados en ambientes teleformativos [Instructional design models used in tele-training environments]. Revista Digital de Investigación Educativa Conect@2,2(1).http://www.revistaconecta2.com.mx/archivos/revistas/revista2/2_2.pdf

Nowak, M. A., \& Highfield, R. (2011). SuperCooperators: Altruism, evolution, and why we need each other to succeed. FreePress.

Potyrała, K. (2020). A few reflections on comtemporary sciencie education and educational research. Problems of Education in the 21st Century, 78(1), 4-8. http://www.scientiasocialis.lt/pec/ node $/ 1260$

Pedró, F. (2006). The new millennium learners: Challenging our views on ICT and learning. http://www. oecd.org/edu/ceri/38358359.pdf

Piscitelli, A. (2009). Nativos digitales: dieta cognitiva, inteligencia colectiva y arquitecturas de la participación [Digital natives: cognitive diet, collective intelligence and architectures of participation]. Santillana.

Plomp, T., \& Nieveen, N. M. (2010). An introduction to educational design research. Enschede: SLONetherlands Institute for Curriculum Development. http://www.slo.nl/downloads/2009/ Introduction_20to_20education_20design_20research.pdf

Prendes, M. P., \& Román, M. (2017). Entornos personales de aprendizaje: Una visión actual de cómo aprender con tecnologías [Personal learning environments: A current vision of how to learn with technologies]. Barcelona: Octaedro.

Prensky, M. (2001). Digital Game Based Learning. McGraw-Hill.

Reig, D. (2010). Un mundo de medios sin fin. Cambios en aprendizaje, Facebook y la apoteosis de las aplicaciones expresivas [A world of endless media. Changes in learning, Facebook and the apotheosis of expressive applications]. In A. Piscitelli, I. Adaime. \& I. Binder (Comps.), El proyecto Facebook y la Posuniversidad. Sistemas operativos sociales y entornos abiertos de aprendizaje [The Facebook project and the Post-University. Social operating systems and open learning environments] (pp. 183- 202). Fundación Telefónica/Ariel.

Richey, R. C., Klein, J. D., \& Nelson, W. (2004). Developmental research: Studies of instructional design and development. En Jonassen, D. (Ed.), Handbook of research for educational Communications and technology, (p. 1099-1130). Lawrence Erlbaum Associates, Publishers.

Roca, R. (2016). Knowmads. Los trabajadores del futuro [Knowmads. The workers of the future] Lid Editorial.

Rose, D. H., \& Meyer, A. (2002). Teaching every student in the Digital Age: universal design for learning. Alexandria, Va: Association for Supervision and Curriculum Development.

Salinas, J., De Benito, B., Pérez, A., \& Gisbert, M. (2018). «Blended learning», más allá de la clase presencial [Blended learning, beyond the on-site class]. RIED, Revista Iberoamericana de Educación a Distancia, 21(1), 195-213. http://dx.doi.org/10.5944/ried.21.1.18859 
Salmon, G. (2000). E-Moderating: The key to teaching and learning online. Kogan Page.

Salmon, G. (2004). E-Actividades, El factor clave para una formación en línea activa [E-Activities, The key factor for active online education]. Editorial UOC.

Sawyer, R. K. (2014). The Cambridge handbook of the learning sciences. Cambridge University Press.

Siemens, G. (2005). Connectivism: A learning theory for a digital age. International Journal of Instructional Technology and Distance Learning, 2(1). http://www.itdl.org/Journal/Jan_05/ article01.htm

Silva, J. (2017). Un modelo pedagógico virtual centrado en las E-actividades [A virtual pedagogical model based on E-activities]. RED, Revista de Educación a Distancia, 53. http://dx.doi.org/10.6018/red/53/10

Silva, J., \& Maturana, D. (2017). Un modelo para introducir metodologías activas en educación superior [A model to introduce active methodologies in higher education]. Innovación Educativa, 17(73), 117-131. http://bit.ly/2QcsIxh

Tapscott, D. (2009). The impeding demise of the university. Edge, The Third Culture. http://www.edge. org/3rd_culture/tapscott09/tapscott09_index.html

Ustun, A.B., \& Tracey, M.W. (2020). An effective way of designing blended learning: A three phase design-based research approach. Education and Information Technologies, 25, 1529-1552. https://doi.org/10.1007/s10639-019-09999-9

Valverde, J. (2010). El movimiento de 'educación abierta' y la 'universidad expandida' [The 'open education' and 'expanded university' model]. Tendencias pedagógicas, 16, 157-180. https:// revistas.uam.es/tendenciaspedagogicas/article/view/1948/2059

Valverde, J. (2019). Guía académica del Máster en Educación Digital [Academic Guide of the Master in Digital Education]. Universidad de Extremadura. https://mastereducaciondigital.unex.es/guiasmed

Valverde, J., Fernández, M.R., \& Garrido, M. (2018). Aprendizaje Basado en Problemas (ABP-PBL) en la formación online de estudiantes de posgrado universitario: un análisis de los niveles de comprensión (taxonomía SOLO) [Problem-Based Learning (PBL) in online training of university students: an analysis of comprehension levels (taxonomy SOLO)]. VIII Congreso Iberoamericano de Pedagogía [VIII Iberoamerican Congress of Pedagogy]. Buenos Aires, Argentina, August 14-17.

Received: February 17, 2021

Accepted: May 30, 2021

Cite as: Fernández-Sánchez, M. R., \& Silva-Quiroz, J. (2021). Emerging educational design in online training in higher education. Problems of Education in the 21 $1^{\text {st }}$ Century, 79(3), 397411. https://doi.org/10.33225/pec/21.79.397

\begin{tabular}{|ll}
$\begin{array}{l}\text { María Rosa Fernández- } \\
\text { Sánchez } \\
\text { (Corresponding author) }\end{array}$ & $\begin{array}{l}\text { PhD, Associate Professor, Department of Educational Sciences, University } \\
\text { of Extremadura, Avda. de la Universidad s/n, C.P. 10.003, Cáceres, Spain. }\end{array}$ \\
E-mail: rofersan@unex.es \\
Website: https://www.researchgate.net/profile/Maria_Fernandez_Sanchez2 \\
ORCID: https://orcid.org/0000-0001-6889-5806
\end{tabular}

